\title{
UDC 37.01.930.85
}

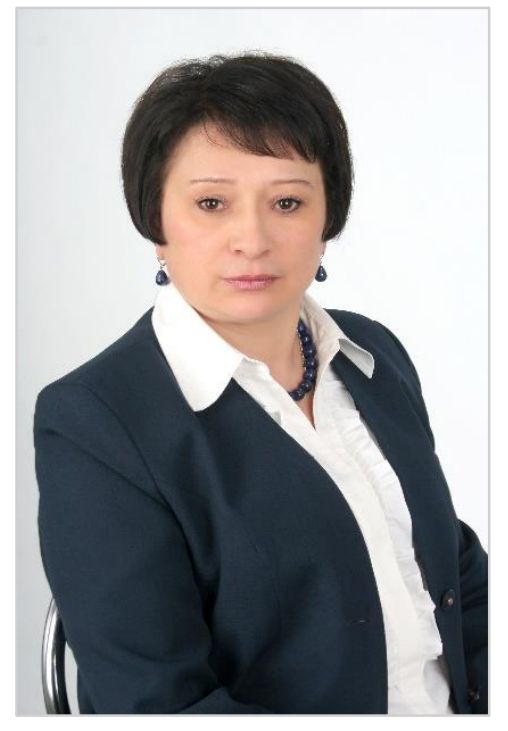

\section{BETWEEN SCYLLA AND CHARYBDIS (School in a Totalitarian Society)}

\author{
Halyna Dokashenko \\ Dr. Hab. in History, Professor, Head of the Domestic and \\ Foreign History Department \\ Horlivka Institute for Foreign Languages \\ SHEI "Donbas State Pedagogical University" \\ Bakhmut, Donetsk region, Ukraine \\ ORCID ID 0000-0002-1428-3182 \\ galinadokashenko@ukr.net
}

Abstract. In the article a rather effective scientific approach is used - the study of totalitarianism through certain spheres of the spiritual life of society, that is the most complex and contradictory sphere of life of the human community.

The object of the study is the school education of Bulgaria in the socialist period from the September 1944 events connected with the rise to power of the Patriotic Front Government to the "palace coup" in 1989, when the country's educators were faced with the choice between deep national traditions of schooling and the unified approaches of the socialist era. The choice of the country is connected with the intention to analyze the situation in education development under the conditions of the Soviet model of the regime other than it was in the USSR, which was called "People's Democracy", and to define the peculiarities of this regime in one of the countries of the former "socialist camp". Among these features it is identified the role of the personal factor in the party - governmental leadership of this Balkan country.

The historical and pedagogical process in Bulgaria is characterized by the indicators of several levels. At the general level, it is shown that the education system is an important component and a leading feature of human civilization. The general pattern (that is, an indicator that applies to all or at least the vast majority of states) of the educational space development of Bulgaria in a certain period was a steady trend of increasing the role of education in public progress, when education and upbringing were focused on reaching all the segments of the population. The peculiarities, inherent in particular groups of states, were the features characteristic for the education development in socialist countries: the party leadership and a strict control of party bodies, ideologization of the educational process and extracurricular work, too high degree of planning, the subordination of state structures to party organs, an excessive centralization, etc; the individual features include the preservation of the national system of public-state leadership in the spiritual sphere, the nonantagonistic coexistence of religious and secular-democratic consciousness of an individual and a high role and place of a Bulgarian teacher in the society. Contrary to the totalitarian rule, the Bulgarian teacher patiently taught children and adults to peace, tolerance and sociability, respect for work and social justice.

Further explorations of the author will be devoted to the analysis of the common features of the education development in the countries of the Balkan region, which have historically been at the intersection of western and eastern trends, under the influence of multi-vector approaches and orientations. 
Key words: totalitarian society; school education; national traditions; unification; dogmatism; revival.

Problem setting in general. Scylla and Charybdis are the maritime monsters of ancient mythology standing for dangerous phenomena that can be circumvented by walking cautiously along a very narrow path. A step to the left or to the right can be the last one. These ancient monsters are used to determine the complexity of organizing education (and the whole cultural sphere of social life) in a totalitarian society. At any time, educators could be accused of being overly inclined to national ideas and traditions, or vice versa of their undervaluation. This situation manifested itself most clearly in the post-war Soviet period, when the ruling political force launched an active struggle against nationalism and cosmopolitanism. This was by no means the only contradiction in the totalitarian society, but this problem is deliberately singled out for consideration. The history of school education in Bulgaria has been chosen as the material for study because this country has deep national traditions in education on the one hand, and, on the other hand, it used to be one of the leading countries of the socalled "socialist camp" with clearly defined features of a totalitarian state. Originally being situated at the crossroads of eastern and western influences, Bulgaria has had a complex and controversial history, including its educational field.

The latest papers and publications on the problem. The works of several directions represents the historiographical basis of the work. Firstly, the research studies carried out by political scientists, sociologists and historians on the causes, purport and consequences of totalitarian regimes (Arendt, 1951; Curtis, 1979; Katsarsky, 2002; Puhach, 2008; Kulchytskyi, 2013 and others); secondly, the scientific works of Ukrainian and Bulgarian researchers with characteristic of this period of historical development in Bulgaria (Chychovska, 1995; Kalynova, 2006; Chornii, 2007; Tsoneva, 2007 and others); and finally, a large group of works, both individual and collective ones, on the history of pedagogy and education in the country from the time of the First Bulgarian Kingdom to the present day (Atanasov, 1998; Kolev, 2002; Georgyeva, 2004 and others).

Formulation of the goals of the article. The author sets the task to reveal the presence of regular patterns, specific peculiarities and individual features in the education system of Bulgaria. The chronological boundaries of the article cover the period 1945 - 1989. The lower boundary is determined by the well-known events at the end of World War II, and the upper boundary is the so-called "palace coup", which means the rejection of Bulgarian society from the socialist version of social development. 


\section{H. DOKASHENKO \\ Between Scylla and Charybdis (School in a Totalitarian Society)}

The theoretical foundations of the study. The theoretical and methodological basis of the work is the philosophical provision on the presence of several levels of knowledge - general, special and individual in each social process and a phenomenon.

School education in Bulgaria of this period is considered at the universal level of human civilization development in general; at the general level, which defines the peculiarities of modern times; at the special level, which characterizes the development of a group of countries of the so-called "socialist camp" and, finally, at the individual level, which outlines the social development of the particular country - Bulgaria. Historical cognition of educational processes has been conducted in the following dimensions: a) a retrospective dimension, aimed at knowledge of the past, b) a presentative one, aimed at awareness and understanding of the present, c) a perspective one, aimed at vision and predicting of the future.

The study was conducted on the basis of civilization approaches, that is, the recognition of a number of socio-economic, scientific and technical, political, and cultural characteristics as a unity.

Presentation of basic research material. The choice of the country - Bulgaria - is determined by several reasons. First of all, this very country has accumulated a number of peculiar forms and directions of development in the educational sphere, which can be defined as national traditions. For example, the democratic principles of governing school education, the main link of which was the special school boards (in Bulgaria they were called school "nastoiatelstva"). They consisted of representatives of the local community, parents, representatives of the educational community, and, of course, members of clegy. In general, the church played a significant role in the organization of school work, as the author of the article has previously written about (Dokashenko, 2004).

Among the achievements in the social sphere of the country can also be considered a significant role of teaching in political, cultural and spiritual life. Thus, in due course, such prominent figures of the national liberation movement as V. Levsky, Hr. Botev, G. Rakovskyi, and L. Karavelov worked as teachers. In the detachment of Hristo Botev there were 11 teachers, almost all the heads of the revolutionary committees in the period 1869-1876 before the liberation of the country from the fivecentury Ottoman domination (heads, their deputies, secretaries and cashiers) had pedagogical experience (Dimitrov, 1987, p.258). The presence of such long-standing traditions formed the basis for the further development of the educational sphere in the democratic direction in the period after World War II, when the struggle for the choice of the historical variant of development began. The main forces of the struggle were the pro-European and pro-Soviet ones. The pro-Soviet forces are known to have won 
and Bulgaria became a member of the socialist camp for almost half a century and took the position of one of the closest to the USSR countries. This proximity is evidenced by the fact of Bulgaria's desire to become the 16th republic of the USSR, which never became a reality. Thus, socialist Bulgaria, on the one hand, inherited deep national traditions in the field of education (democratic principles of school leadership, the role of teaching, the positive role of the church), on the other hand, presented itself as a "faithful follower" of the Soviet system.

In these contradictory and ambiguous tendencies the school education of the country was developing from 1944 (the rise to power of the Patriotic Front Government) to the afire mentioned "palace coup". The geopolitical situation in postwar Europe profoundly changed the socio-political life of Bulgaria, and the education system found itself between national traditions and political imperatives.

Under the influence of a number of internal and external factors, the country gradually entered the orbit of socialist modernization and the task of educators was to combine such existing traditions as the advanced didactic and methodical techniques, the existence of public and private schools, a high level of patriotic education, an increased public attention to educational issues, an active civic position of Bulgarian teachers, etc. with new influences: a full nationalization of education, the unification of the educational process, a high degree of influence of political factors, etc.

In that combination, it was difficult to achieve harmony and, according to the studied materials, the main feature of the Bulgarian school education for the four decades was the constant fluctuations from the traditional national variant of educational development to the new socialist school model.

There are several periods in the development of the Bulgarian school from 1944 to 1989; each of them has its own specificity and a certain internal logic.

The first period covers the time from September 1944 to the end of 1948, that is, from the establishment of the authority of the Patriotic Front to the adoption of the new Law on the Education and conducting of the epochal V Congress of the Bulgarian Communists, characterized by a rather fierce struggle for the prospects of further social development. In this period, the reforms of the tasks, nature and structure of the education system were actually implemented. The position of the central government body, which managed basic, secondary and higher education, was quite confidently occupied by the Ministry of People's Education, which actively cooperated with the sectoral ministries in the aspect of coordination and unity of management of vocational education, with the Higher Educational Committee (HECommittee) as a permanent body of the Council of Ministers, with the Higher Educational Council (HECouncil) as a public-state body, with the Education Workers Union as the main public organization 
of educators. The tradition of public-state care of education, founded by M. Drinov, during this period manifested itself in the leading role of the state with the active participation and assistance of the public.

Contrary to the intention of one of the main political forces - the Bulgarian Workers' Party (Communists) to dominate the education administration, the pluralism of the educational leadership was maintained by the inclusion of representatives of other political forces that were members of the Patriotic Front (PF) in the lineup of HECommittee and HECouncil. The regional governing bodies, the district and district school inspectorates, and the relevant commissions were gradually reformed. Changes in their statutes, functions and lineup took place in the spirit of the PF program. The activities of school boards were organized in the same vein, they interacted with the school's administrative and management staff, the parent community, self-governing children's and youth organizations.

The second period (1948-1959) was marked by the establishment of an active party control by the BCP, which had almost reached the monopoly on power. Since 1949, it had become a constant practice to guide education through the adoption of joint decisions by the party and state leadership, represented by the Central Committee of the Bulgarian Communist Party and the Council of Ministers. The educational process is politicized and ideologized both within school (changes in curricula, programs, etc.), and in extracurricular activities (participation in political actions, introduction of new holidays, etc.). The massive and compulsory enrollment of children and adolescents by actually nationalized youth organizations contributed to the achievement of the basic purpose of education set out in the 1948 Act (Закон за народната просвита, 1948), the comprehensive physical and spiritual development of children in the spirit of socialism. At the same time, illiteracy was almost completely overcome, the possibility of creating and developing schools for national minorities was given, material and moral encouragement of teaching work was strengthened.

The main feature of the third period (1959-1969) is the restructuring of the education system based on the principle of close connection of education and upbringing of young people with socially useful and productive work, which was declared in the relevant Law of 1959 (Закон за по-тясна връзка на училището с живота и за по-нататъшното развитие на народното образование в НР България, 1959). During this period new types of educational establishments were created: vocational schools, secondary vocational schools, technical schools; a traditional school was turned into a secondary polytechnic school. The changes in the nature of education led to new priorities of the organizational and administrative component: the provision of compulsory primary education ( 7 forms), the introduction of industrial 
training at secondary polytechnic school, the development of a network of vocational schools and organization of practical work in them in view of the needs of the national economy.

The party control over the school work was continued and intensified, it was manifested in the usurpation of the right to determine the strategy for the development of this sphere by party bodies, at the state level it was manifested in the decisions of joint plenums of the Central Committee of the Bulgarian Communist Party and the Council of Ministers, and at the regional level - in joint events of party committees and people's councils. For example, after each party congress, the relevant ministry developed a system of measures to implement the congress decisions (Бюлетин на Министерството народна просвіта, 1972, № 6). Another form of the party control was the removal and duplication of the state education authorities' functions by party organizations, which resulted in restriction on the freedom of creativity and local teacher initiative. School was put in full dependence and administrative subordination to the higher hierarchies of the management structure.

At the fourth stage (1969-1979), the gradual convergence and merger of general and vocational education into a single secondary polytechnic school (SSPS) was made. Through the joint efforts of scientists and practitioners computer training, a reduced working week, schooling for children from six years of age were introduced experimentally, the attempts to implement scientific organization of work and create long-term scientific programs were made, etc. Increased unification and focus on an abstract average student became a prerequisite for the demotivation of teaching, the decline in its quality and, as a consequence, the significant decline in its prestige.

At the same time, the volume of financing of educational institutions increased, their distribution was carried out centrally through Ministry of Public Education and the Council of Ministers (Основни положения на реформата в образователната система на НРБ, 1969). The latter decided solely the fate of the submitted proposals. Such a mechanism was another confirmation of the command-administrative approach in the area of financial management of school.

The fifth ten-year period (1979- 1989), for the entire socialist world was the time of constant declaration of new reforms and changes, the implementation of which never took place or even worsened the socio-economic and political situation. The basic principles of education development were defined as generality, obligation and free of charge; social, state and secular character of education, connection of school with life. An attempt to retain control over the spiritual sphere of society was the decision to move to a state-public system of management of cultural and educational institutions, which sounded like a revival of an ancient national tradition (Тезиси за 


\section{H. DOKASHENKO \\ Between Scylla and Charybdis (School in a Totalitarian Society)}

развитието на образователното дело в НРБ, 1979). To turn this system into a real plane, there were several conditions to be fulfilled: the real pluralism of ideologies and the rejection of the Communist Party' monopoly power, the ruling circles' high degree of trust in educators, the desire to disseminate certain scientific experiments to the public at large, and finally, the rejection of declarative nature. The then totalitarian authorities could not and did not want to fulfill these conditions, so the society simply gave up such power.

Thus, the forty-year experience of Bulgaria showed that it is impossible to combine national traditions (significant achievements in the field of education, public attention to school and teachers, public foundations of school management, nonantagonistic existence of religious and secular-democratic consciousness of a person), based on democracy and respect for education, with the variant of a socialist school, when educators are turned from active subjects of the educational space into its observers. The party control became the main feature of this period, because even the proposed periodization is associated with specific party events and decisions: V Congress (1948), the Basic Provisions of the Education System Restructuring (1959), Theses on the Development of Education (1979) etc. However, unlike other countries of the "socialist camp", in Bulgaria at least attempts were made to take into account the national traditions, and this can be explained, firstly, by the historically active position of Bulgarian educators in the society; and secondly, by the subjective factor that is connected with the activities of L. Zhivkova, who, as a member of the family of the party leader and the state, had many more opportunities, and she was allowed to carry out experimental development. One of such experiments was the statepublic system of educational guidance.

Thus, on the whole, the party leadership and subordinate dependence determined the command and administrative character of the school organism during the period under study.

The conclusions and the perspectives of further research. A significant place among the Slavic countries in terms of the level of education development in general and school education in particular belongs to the Republic of Bulgaria, which in the early Middle Ages created the original national school. Its foundations were constantly evolving, experiencing both times of upgrowth, and periods of foreign domination, but it never knew the times of complete decline - neither during the five-century Ottoman domination nor during the totalitarian regime. The peculiarities of the country's education development became, first of all, the presence of powerful national traditions of education development in the previous period, especially during the period of Liberation from Ottoman domination. The education of this period was a leading 


\section{H. DOKASHENKO}

Between Scylla and Charybdis (School in a Totalitarian Society)

component of the national consciousness formation, and teachers played an important role in the national liberation movement. Secondly, in the conditions of the totalitarian system domination of the leadership of socialist Bulgaria, it was compelled to take into account these traditions and sufficiently careful implement reforms and changes. This has affected the reproduction of the state-public system of educational leadership, the constant desire to bring the educators closer to the power, the creation of certain conditions for acquaintance with the world practice of educational development, etc. As a result, Bulgaria, among all the countries of the "socialist camp", had the least developed dissident movement, which came down mainly to the environmental movement. Further explorations of the author will be focused on determining of the place and role of education in the historical development of the Balkan countries and their importance in the formation of civilizational foundations of social development.

\section{REFERENCES}

1. Act for a closer connection of school with life and for the further development of public education in the People's Republic of Bulgaria (4.07.1959). 15 godini narodno obrazovanie, 40-52.

2. Activities of the Ministry of Public Education for the implementation of the 10th Congress of the Bulgarian Communist Party and the unified plan for socio-economic development of the People's Republic of Bulgaria in 1972 and the Sixth Five-Year Plan in the field of education (1972). Byuletin na MNP, 6, 10-18.

3. Arendt, Hannah (1951). The Origins of Totalitarianism. New York, USA: Harcourt, Brace \& Co.; London Great Britain: Secker \& Warburg.

4. Atanasov, J. (1984). History of Bulgarian Education (Lecture Course). Sofia, Bulgaria: Kliment Ohridski.

5. Chychovska, V. (1995). The policy against the Enlightenment tradition. Sofia, Bulgaria: Kliment Ohridski.

6. Chornii, V. (2007). History of Bulgaria. Lviv, Ukraine: PAIS.

7. Curtis, M. (1979). Totalitarianism. New Brunswick. New York, USA: Transaction Books.

8. Dimitrov, A. (1987). School, progress and the national revolution. The Bulgarian School during the Renaissance. Sofia, Bulgaria: BAS Publishing House.

9. Dokashenko, G. (2004). On the role of the church in the formation and development of Bulgarian education: a historical aspect. Problemy osvity. Naukovo-metodychnyi zbirnyk, 284 - 287.

10. Georgyeva, S. (2004). History of Bulgarian Education. Ruse, Bulgaria: University Publishing House. Paradigm.

11. Kalynova, E. \& Baeva, I. (2006). Bulgarian Transitions 1939 - 2005. Sofia, Bulgaria:

12. Katsarsky, I. (1994). Totalitarian socialism. Sofia, Bulgaria: Paradigm. Rilski.

13. Kolev, J. (2002). History of Bulgarian Education. Blagoevgrad, Bulgaria: Neophyte

14. Kulchytskyi, S. (2013). Totalitarianism. Entsyklopediya istoriyi Ukrayiny, 10, 131.

15. Main points of the reform in the educational system of the People's Republic of Bulgaria (31.07.1969). Byuletin na MNP, 8-9, 14-24.

16. Public Education Act (September 1948). Sofia, Bulgaria: State Printing Office. 
17. Puhach, E. (2008). Establishment of totalitarian regimes in the countries of Central and South - Eastern Europe. Kharkov Ukraine: Kharkiv National University. V. Karazin.

18. Tsoneva, P. (2007). The Management of the School in Bulgaria from the Beginning of the Nineteenth Century to 1989. Sofia, Bulgaria: Kliment Ohridski.

19. Zhivkov, T. (1979). About the Development of the Educational Business in the People's Republic of Bulgaria. Sofia, Bulgaria: Communist Party Publishing House.

\title{
МІЖ СЦИЛЛОЮ ТА ХАРИБДОЮ (школа в тоталітарному суспільстві)
}

\author{
Галина Докашенко \\ доктор історичних наук, професор, \\ завідувач кафедри вітчизняної та зарубіжної історії \\ Горлівського інституту іноземних мов \\ ДВНЗ «Донбаський державний педагогічний університет», \\ м. Бахмут Донецької обл., Україна \\ ORCID ID 0000-0002-1482-3182 \\ galinadokashenko@ukr.net
}

\begin{abstract}
Анотація. У статті використано достатньо ефективний науковий підхід - дослідження тоталітаризму через окремі сфери духовного життя суспільства, яке є найбільш складною й суперечливою сферою життєдіяльності людської спільноти. Об'єктом дослідження стала шкільна освіта Болгарії в соціалістичний період від вересневих подій 1944 р., пов'язаних із приходом до влади уряду Вітчизняного фронту, до «палацового перевороту» 1989 р., коли освітяни країни опинилися перед вибором між глибокими національними традиціями шкільництва та уніфікованими підходами соціалістичної доби. Вибір країни пов'язаний із прагненням проаналізувати ситуацію в освіті в умовах іншого, в порівнянні із СРСР радянського зразка, режиму, який отримав назву «народної демократії», визначивши особливості цього режиму в одній із країн колишнього «соціалістичного табору». Серед цих особливостей визначено, зокрема, і роль особистісного фактору в партійно- урядовому керівництві цієї Балканської країни.

Історико-педагогічний процес у Болгарії охарактеризовано показниками кількох рівнів: на всезагальному рівні засвідчено, що система освіти $є$ важливою складовою частиною та провідною ознакою людської цивілізації. Загальною закономірністю (тобто показником, який стосуються всіх або, принаймні, переважної більшості держав) розвитку освітнього простору Болгарії в означений період стала неухильна тенденція зростання ролі освіти в суспільному поступі, коли навчання й виховання орієнтовані на охоплення всіх верств і груп населення. Специфічними особливостями, притаманними окремим групам держав, стали ознаки, характерні для розвитку освіти соціалістичних країн: партійне керівництво і суворий контроль партійних органів, ідеологізація навчального процесу та позашкільної роботи, занадто високий ступінь плановості, підпорядкованість державних структур партійним органам, надмірна централізація та ін.; до індивідуальних рис віднесено збереження національної системи громадсько-державного керівництва духовною сферою, неантагоністичне співіснування релігійної та світсько-демократичної свідомості особи та високу роль і місце болгарського вчителя в суспільстві. Всупереч тоталітарному правлінню, болгарський учитель терпляче вчив дітей і дорослих миру, толерантності й комунікабельності, повазі до праці й соціальній справедливості.
\end{abstract}




\section{H. DOKASHENKO}

Between Scylla and Charybdis (School in a Totalitarian Society)

Подальші розвідки автора будуть присвячені аналізу спільних рис освітнього розвитку країн Балканського регіону, які історично перебували на перехресті західних та східних тенденцій, під впливом різновекторних підходів та орієнтацій.

Ключові слова: тоталітарне суспільство, шкільна освіта, національні традиції, уніфікація, догматизм, відродження.

\section{СПИСОК ВИКОРИСТАНИХ ДЖЕРЕЛ}

1. Атанасов, Ж. (1984). История на българското образование (лекционен курс). София, България: Климент Охридски.

2. Георгиева, С. (2004). История на българското образование. Русе, България: издателство университета.

3. Димитров, А. (1987). Училището, прогресът и наџионалната революиия. Българското училище през Възраждането. София, България: издателство на БАН.

4. Докашенко, Г.(2004). Про роль церкви в становленні та розвитку болгарської освіти: історичний аспект. Проблеми освіти. Науково-методичний збірник, $284-287$.

5. Живков, Т. (1979). За развитието на образователното дело в Народна Република България. София, България: Партиздат.

6. Закон за народната просвита (Септември 1948 г.). София, България: Державна печатница.

7. Закон за по-тясна връзка на училище то с живота и за по-нататъшното развитие на народното образование в НР България (4.07.1959 г.). 15 години народно образование, 40-52.

8. Калинова, Е. и Баева, И. (2006). Българските преходи 1939 - 2005. София, България: Парадигма.

9. Кацарски, И. (1994). Тоталитарният социализъм. София, България: Парадигма.

10. Колев, Й. (2002). История на българското образование. Благоевград, България: Неофит Рилски.

11. Кульчицький, С. (2013). Тоталітаризм . Енциклопедія історії Украӥни, 10, 131.

12. Мероприятия на Министерството народна просвета за изъпълненията на X-ия конгрес на БКП и единния план за обществено-икономическо развитие на НРБ през 1972 г. и VI-та петилетка в областта на образованието (1972). Бюлетин на МНП, 6, 10-18.

13. Основни положения на реформата в образователната система на НРБ (31.07.1969 г.). Бюлетин на МНП,8-9, 14-24.

14. Пугач, Є. (2008). Встановлення тоталітарних режимів у країнах Центральної та Південно - Східної Європи. Харків Україна: ХНУ ім. В.Каразіна.

15. Цонева, П. (2007). Управлението на училището в България от началото на ХІХ век до 1989 година. София, България: Климент Охридски.

16. Чичовска, В. (1995). Политиката срещу просветната традиция. София, България: Климент Охридски.

17. Чорній, В. (2007). Історія Болгарії. Львів, Україна: ПАІС.

18. Arendt, Hannah (1951). The Origins of Totalitarianism. New York, USA: Harcourt, Brace \& Co.; London Great Britain: Secker \& Warburg. Books.

19. Curtis, M. (1979). Totalitarianism. New Brunswick. New York, USA: Transaction

Матеріали надійшли до редакції 27.08.2019 p. 